\title{
Monetary Policy and Euro Zone Governance in the EMU
}

\author{
Herwig C.H. Hofmann
}

\section{A Introduction}

One of the European Union's most ambitious policy projects to date is the 'economic and monetary union whose currency is the euro' (EMU, Article 3(4) TEU). The EMU's two polices - the economic union and the monetary union - are an unequal set of twins. On one hand, the monetary union's central elements are well-developed: as an element of substance, the introduction of the euro as a single currency; as an institutional achievement, the creation of the European System of Central Banks (ESCB) together with the European Central Bank (ECB) on the EU level as a highly independent body having the power to adopt a diverse range of measures. Additionally, the Treaties contain specific provisions on the goals and principles of monetary policy.

Economic union within the European Union is, on the other hand, is much less developed. The Maastricht Treaty's approach was to leave economic - and fiscal - policies largely within the competence of the Member States establishing only loose mechanisms of intergovernmental cooperation. Market pressures, so the original thinking behind the loose structure, would in the long run ensure that national policy choices by the democratic parliaments and governments on Member State level align to form a coherent whole. Since 2009, though, a host of more or less directly binding measures for enhancing economic policy cooperation have emerged in Union law, adding to the initial 'light-touch' approach.

Irrespective of the very different treatment of the monetary and economic policies in the EMU, the two are highly inter-related, not least due to the fact that monetary policy often indirectly affects the conditions under which economic policy can be exercised. ${ }^{1}$ Monetary policy takes place alongside, and in coordination with, fiscal policy measures (including taxation, debt-financing of public budgets, and allocation of available funds through national budgets, including social security systems). The broader economic policy orientation of Member States also includes issues of regulation, for example, through labour, competition, environmental, or energy law. Monetary policy is created by reacting to, and in effect commenting upon, the economic policy decisions of Member States. In carrying out its task of constructing an efficacious monetary policy for the euro zone, the ECB cannot ignore either the structure nor the state of the economy. In fact, it may well have available to it more information about the reality of the economic situation than some Member State governments themselves. Therefore, drawing the boundary between the two policy fields is not easy. The ECB, as a highly specialised European body with key monetary policy functions may risk, directly or indirectly, affecting the conditions for the creation of an economic policy.

Against this background, this chapter addresses the elements of the EMU relevant to an enquiry into the administrative system, workings, and law of the Union specifically in this sector. These elements include the role of the ECB - a highly independent body, functioning on a non-majoritarian and expertise-driven basis - in the field of monetary policy. The chapter also enquires into economic governance, which relies on intergovernmental cooperation leading to a wide range of forms of executive action (under EU, public international, and private law). Yet a further element, highly relevant to consideration of sectoral administration and administrative law, is the emergence of new types of reporting, surveillance, and compliance mechanisms. The chapter, therefore, enquires, first, into the concepts of (EU) administrative law which can be successfully applied to the fields of monetary and perhaps even economic policy, and, secondly, into what can be learnt for the wider field of (EU) administrative law from the EMU as a sectoral focus. Where appropriate, the chapter compares the approaches taken with regard to the monetary as opposed to economic policy.

\section{$B$ Sources of law and the definition of administrative tasks in the Economic and Monetary Union}

The objectives and administrative tasks of the EMU are outlined in Article 119 TFEU, according to which the activities of the Member States and the Union within the field of monetary policy include:

- 'the adoption of an economic policy which is based on the close coordination of Member States' economic policies, on the internal market and on the definition of common objectives, and conducted in accordance with the principle of an open market economy with free competition'; ${ }^{2}$ and

This is explicitly acknowledged by the CJEU in C-62/14 Peter Gauweiler and Others v Deutscher Bundestag of 16 June 2015 paras. 52 and 58.

$2 \quad$ Art 119(1) TFEU. 
- creating and administering 'a single currency, the euro, and the definition and conduct of a single monetary policy and exchange-rate policy....?

The distinction between economic and monetary policy reflects the mixed approach to the legal competences of the Union. Under Article 3(1)c) TFEU, the monetary policy of Members States who have adopted the euro is an exclusive competence of the Union. Economic policy, on the other hand, as identified in Article 5(1) TFEU, is a policy field of coordination, with the possibility of a (not further defined) third category of 'specific provisions', applicable to euro member states. A possible explanation for the distinction between the monetary and the economic policy in the Treaties is the earlier assumption that the key to stable economic growth was a 'sound' monetary policy, conducted by technical experts in independent central banks. ${ }^{4}$ Active fiscal policy was deemed counterproductive for this purpose, and it thus appeared inopportune to give to the monetary union governance or regulatory capacities for coordinating its member states' fiscal policies. ${ }^{5}$ The fact that the distinction identified here allowed for the creation of a monetary union without the necessary transfer to the EU of a wide range of powers over fiscal and general economic policy might help explain the striking structural differences in the monetary and the economic union within the EMU.

\section{SOURCES OF LAW AND DEFINITION OF TASKS IN THE MONETARY UNION}

Articles 127 et seq. TFEU constitute the legal basis for the policies pursued in the EU's monetary union. These provisions provide for the specific institutional design necessary in the field of monetary policy of the euro zone as well as the administrative powers in regard to monetary law and policy in the Union.

According to Article 127 TFEU itself, 'the primary objective of the European System of Central Banks (ESCB) is to maintain price stability'. Without prejudice to this objective, monetary policy is to support the 'general economic policies in the Union with a view to contributing to the achievement of the objectives of the Union as laid down in Article 3 of the TEU'. To that end, the ESCB shall (under Article 127(2) TFEU):

- 'define and implement the monetary policy of the Union',

- conduct foreign-exchange operations (consistent with the provisions of Article 219 TFEU),

- hold and manage the foreign reserves of the Member States, and

- 'promote the smooth operation of payment systems'.

The ECB has, under Article 282(3) TFEU, the central function to 'authorize the issue of the euro'. In that respect, Article 128(1) TFEU and Article 16 Statutes of the ESCB/ECB accordingly empower the ECB's Governing Council with the 'exclusive right to authorise the issue of euro banknotes within the Union'. The latter are issued by the ECB and the National Central Banks (NCBs). Coinage, by way of contrast, is a prerogative of the NCBs but this power also is exercise within the strictly coordination of the ESCB.

Irrespective of this essentially technical function, one of the distinctive specificities of the policy area of monetary policy is the fundamentally political nature of the powers conferred on a very independent administrative body designed with a maximum concentration of expertise. Under the system established by the Treaties, the ECSB and the ECB are in charge of defining monetary policy, and subsequently implementing it by means of rule-making and single-case implementation by means of decisions, information management, and engaging in contractual activities. These tasks and modes of operation are further underpinned by Article 282(4) TFEU which established that the ECB 'shall adopt such measures as are necessary to carry out its tasks'. Its 'monetary functions', specified in Articles 18-20 Statutes of the ECSB/ECB, are to be exercised either by the ECB or by the NCBs:

- First, under Article 18 Statutes of the ECSB/ECB, the 'ECB shall establish general principles for open market and credit operations carried out by itself or the national central banks', 'open market' activities being contractual activities including:

- 'buying and selling outright (spot and forward) or under repurchase agreement';

- 'lending or borrowing claims and marketable instruments, whether in euro or other currencies, as well as precious metals';

- conducting 'credit operations with credit institutions and other market participants, with lending being based on adequate collateral'.

Art 119(2) TFEU.

Peter A. Hall, The Mythology of European Monetary Union, 18 Swiss Political Science Review (2012), 508-513 at 508.

Tal Sadeh, Amy Verdun, Explaining Europe's Monetary Union: A Survey of the Literature, 11 International Studies Review (2009), 277301 at 285 with further references. 
- Secondly, again under Article 18 Statutes, the ECB is obliged to conduct an information policy 'for the announcement of conditions under which they stand ready to enter into such transactions'.

- Thirdly, Article 19 Statutes ECSB/ECB specifies that the ECB holds minimum reserves. This activity is typically regulatory in nature, in that the ${ }^{`} \mathrm{ECB}$ may require credit institutions established in Member States to hold minimum reserve on accounts with the ECB and national central banks in pursuance of monetary policy objectives'. The ECB's Governing Council has the power to establish 'Regulations concerning the calculation and determination of the required minimum reserves'. These regulations may also identify sanctions since in 'cases of noncompliance the ECB shall be entitled to levy penalty interest and to impose other sanctions with comparable effect'. The regulatory activity, therefore, takes place vis-à-vis private actors.

- Fourthly, under Article 20, the 'ECB and national central banks may provide facilities, and the ECB may make regulations, to ensure efficient and sound clearing and payment systems within the Union and with other countries'. That authorisation is, according to the General Court, to be interpreted narrowly, as are all specific allocations of powers. In $U K v E C B$ the court held, for example, that the power to ensure clearing and payment systems confers powers explicitly only for clearing of payment systems, but not for clearing of securities, even though one might argue that the latter may, in some transactions, be linked to the former. ${ }^{6}$

- Additionally, the Statutes ECSB/ECB contain further in Article 20 an open empowerment, allowing the ECB Governing Council (by a majority of two thirds of the votes cast), to 'decide upon the use of such other operational methods of monetary control as it sees fit' as long as the general provisions of Article 2 Statutes ESCB/ECB are complied with. Measures under Article 20 can, therefore, be adopted to ensure any of the objectives listed in Article 127(1) and Article 282(2) TFEU.

Primary law is fleshed out by secondary legislation, for example, concerning the 'use of the euro as single currency' which can be adopted under the ordinary legislative procedure (Article 133 TFEU). The Council may also adopt, under the special legislative procedure of Article 127(6) TFEU, regulations for the conferral on the ECB of special tasks concerning policies relating to supervision of banks and other financial institutions. ${ }^{7}$ Another special legislative procedure applies under Article 129(4) TFEU regarding subordinate regulatory powers on matters such as minimum reserves (Article 19.2. Statutes ESCB/ECB), methods of monetary control (Article 20 Statutes ESCB/ECB), the conditions of capital increases of the ECB (Article 28.1. Statutes $\mathrm{ESCB} / \mathrm{ECB}$ ), and the imposition of fines or periodic penalty payments on undertakings for failure to comply with obligations under the ECB's regulations and decisions.

The ECB has its own regulatory powers conferred on it pursuant to Article 132(1) TFEU and Article 34 Statute ESCB/ECB. There is a delicate balance between acts of the Council and those of the ECB. This can be illustrated by the fact that fundamental decisions regarding, for example, minimum reserves of banks are reserved to Council regulations adopted in the special legislative procedure. Within this framework, Council provisions may require credit institutions established in Member States to hold minimum reserves on accounts with the ECB and with national central banks in pursuance of monetary policy objectives. Regulations concerning the calculation and determination of the required minimum reserves may be established, however by the ECB. ${ }^{8}$

Monetary policy of the Union is further implemented by NCBs for which national administrative law and private law is applicable. Some aspects of Union monetary policy also need to be implemented in national law by Member States which have not adopted the euro.

\section{SOURCES OF LAW AND DEFINITION OF TASKS IN THE ECONOMIC UNION}

A very different picture emerges regarding economic policy of the Union. Very few legal provisions had been adopted in regard to this policy prior to the onset of the economic crises in 2008. The Treaty of Maastricht had

$6 \quad$ T-496/11 United Kingdom v European Central Bank ECLI:EU:T:2015:133 of 4 March 2015, paras 99-105: 'the existence of an implicit regulatory power, which constitutes a derogation from the principle of conferral laid down by Art 13(2) TEU, must be appraised strictly. It is only exceptionally that such implicit powers are recognised by case-law and, in order to be so recognised, they must be necessary to ensure the practical effect of the provisions of the Treaty or the basic regulation at issue (see, by analogy, judgment in France v Commission, paragraph 104 above, EU:T:2007:290, paragraph 37).'

7 One example for this is Council Regulation (EU) No 1024/2013 of 15 October 2013 conferring specific tasks on the European Central Bank concerning policies relating to the prudential supervision of credit institutions, OJ 2013 L $287 / 63$.

8 One ECB regulation with a considerable impact on the relation between the is Regulation 1745/2003 (OJ 2003 L 251/10) which delegates powers especially in the field of administration of minimum reserves of banks to the national central banks (see e.g. Articles 9, 10 Reg 1745/2003). 
left a potential 'economic policy union' incomplete despite fact that the 'the monetary and economic union' (Article 3 TEU) contained 'two integral parts of a single whole' which would have to be implemented in parallel.'

In this respect, the measures concerning economic policy coordination developed in the wake of the economic and financial crises have inter alia aimed at developing the conditions of a more integrated monetary - as well as economic - policy in the EU. Not only has economic policy been increasingly coordinated through the use of a great diversity of tools (often developed in an ad-hoc manner), which arguably have taken the design of economic policy away from a more political to a more expert-driven administrative setting. As well, Gauweiler highlights how the exercise of tools belonging primarily to monetary policy can, and will, have effects on the conditions of the exercise of economic policy. ${ }^{10}$

Initially, the economic union was shaped primarily through mutual information and evaluation procedures which were introduced as means of coordinating Member States' economic policies. ${ }^{11}$ Under the Lisbon Strategy for the coordination of the economic and employment developments of the Member States, one of the key measures employed was the so called open method of cooperation (OMC) of the time, ${ }^{12}$ within which Member States produced National Reform Programmes co-evaluated on the EU level. The establishment and reporting of such national programmes entailed the reporting of key data on economic development and employment.

The first step in giving this executive cooperation more solid form by means of 'multilateral surveillance' (Article 126(3) TFEU) came with the Stability and Growth Pact (SGP) concluded in 1997. This involved the production of so called stability and convergence reports by Member States, to be substantiated by relevant data, and their subsequent review of by the Commission and the Council. The SGP, based on Article 126 TFEU (ex Article 104c TEC) in conjunction with the Protocol on the Excessive Deficit Procedure annexed to the Treaty, was the means by which the European Council concluded measures designed to address the disparity between a common monetary policy and the divergent economic and fiscal policies of the Member States. The SGP in force today has seen several amendments and enhancements, mostly ad-boc in reaction to economic problems, without having a pre-existing constitutional template and list of administrative tasks. ${ }^{13}$ These amendments have been marked by an intensification of the coordination between the Member States, and an increase in prescriptive rules for compliance. ${ }^{14}$

In reaction to further economic crises since 2008, the EU has had to find ways to deal with various emergency situations, including threats of collapse of individual Member State economic systems. Thus, between late 2010 and 2012, a comprehensive reinforcement of economic governance in the EU and the euro area saw the establishment of institutional structures such as the European Stability Mechanism (ESM), ${ }^{15}$ the European Financial Stabilisation Mechanism (EFSM) ${ }^{16}$ and the European Financial Stability Facility (EFSF), ${ }^{17}$ as agreements under public international law outside the Treaty framework. Reliance on public international law was not uncontroversial, but had become necessary because of the lack of unanimity in Council. In Pringle the CJEU declared this approach legal. ${ }^{18}$ However, the negative consequence of the intergovernmental approach is

9 Committee for the Study of Economic and Monetary Union, Report on economic and monetary union in the European Community, (Brussels 1989).

10 Case C-62/14 Peter Gauweiler and Others v Deutscher Bundestag of 16 June 2015 paras. 52 and 58 and Opinion of Advocate General Cruz Villanón of 14 January 2015. At the heart of the dispute in Gawweiler was whether the European Central Bank's (ECB) announcement of summer 2012 that it would be purchasing on a large scale government bonds issued by States of the euro area, known as the 'OMT programme', was in fact an economic policy measure, which would fall outside of the ECB's mandate in the field of monetary policy.

11 See Arts. 102a and 103 EC. Multilateral surveillance formally began in 1990 and was subsequently governed by Council Decision 90/141/EEC of 12 March 1990 on the attainment of progressive convergence of economic policies and performance during stage one of economic and monetary union, 24.3.1990 L78/3. See also Art. 104c EC and the Protocol on the Excessive Deficit Procedure.

12 Curtin, Democratic Accountability of Executive Power, in: Frederico Fabrini, Ernst Ballin, Han Somsen (eds.) What form of government for the European Union and the Eurozone, Hart (Oxford 2015) 171-196, at p. 179; Kenneth Armstrong, The New Governance of EU Fiscal Discipline, 38 European Law Review 2013, 601, at p. 609.

13 For an overview see https://ec.europa.eu/info/business-economy-euro/economic-and-fiscal-policy-coordination/eu-economicgovernance-monitoring-prevention-correction/stability-and-growth-pact en (last accessed on 1 March 2017).

14 Deirdre Curtin, Democratic Accountability of Executive Power, in Frederico Fabrini, Ernst Ballin, Han Somsen (eds.) What form of government for the European Union and the Eurozone, Hart (Oxford 2015) 171-196, at p. 179.

15 The European Stability Mechanism (ESM) is the permanent crisis resolution mechanism for the countries of the euro area. The intergovernmental treaty establishing the ESM was adopted on 2 February 2012.

16 The European Financial Stabilisation Mechanism, legally based in Art. 122 (2) TFEU, is a programme whose purpose is to provide loans to EU Member States in financial difficulty.

17 The European Financial Stability Facility, is a special purpose vehicle, outside the EU Law framework, established as a private company under Luxembourg law with the Member States as shareholders.

18 Case C-370/12 Pringle of 27 November 2012 ECLI:EU:C:2012:756.; with much literature having discussed the legality of the structure. See e.g. See for instance, Mathias Ruffert, 'The European Debt Crisis and European Union Law’ (2011) 48 C.M.L. Rev. 
that it excludes recourse to existing mechanisms of democratic accountability within the Union, while considerably strengthening powers of the executive branch of Member States. (In regard to the latter sometimes subject to parliamentary - national democratic - scrutiny, but not necessarily thereby contributing to or strengthening a pan-European policy perception.) One example of this was the creation and empowerment, in matters of fiscal and economic policy, of the 'Eurogroup', an informal gathering of national finance ministers, (recognised however in Article 137 TFEU and Protocol No 14) for inter alia the adoption of semi-annual work programmes. The Eurogroup, supported by the Eurogroup Working Group, has a president with agenda-setting powers, supported by a secretariat. Its president is also the chair of the board of governors of the ESM. Despite being able to exercise significant influence in the context of economic cooperation, Working Group decisions are not binding, as confirmed by the General Court in Mallis. ${ }^{19}$

On the basis of Union law, the first step towards the coordination of the budgetary, structural, and macroeconomic policies of the euro zone States was the adoption, ${ }^{20}$ upon the Commission's proposal, ${ }^{21}$ of the so called 'European Semester', ${ }^{22}$ legally enshrined in Articles 121 and 148 TFEU. This consists of a six-month cycle based on surveillance and ex ante monitoring of the Member States' economic, structural, and budgetary policies. This process grants to the Commission far reaching administrative powers, allowing it to review the Member States' budgets, and to assess whether the national draft budgetary plans comply with the SGP criteria as further established by the Commission in guidance documents. ${ }^{23}$ The analysis of the Commission results, at the end of the calendar year marking the beginning of the 'semester cycle', in two reports: an 'annual growth survey' and an 'alert mechanism report'. These reports are adopted by the Council, and the conclusions adopted by the European Council, in an effort directed at taking the old OMC approach to both of these institutions. The Commission, then, on this basis, drafts Country Specific Recommendations, again to be adopted by the Council. Based on the findings of these reviews, the Commission may trigger procedures to pressure Member States into changing their economic policies through the so called 'European semester macroeconomic imbalances procedure' (MIP). The Commission's recommended policy responses to the imbalances are integrated into its 'country specific recommendations' (CSR), published annually in respect of all Member States. ${ }^{24}$ These recommendations are, then, documents emerging from the Union administration with the objective of guiding Member State economic policy, and of intensifying economic policy coordination.

A further set of measures, the 'Six-Pack Agreement' (based on Articles 121, 126 and 136 TFEU) comprises five regulations and one directive on macroeconomic imbalances and fiscal policies. ${ }^{25}$ These measures are

1777,1785; Richard Palmstorfer, 'To bail out or not to bail out? The current framework of financial assistance for euro area Member States measured against the requirements of EU primary law' (2012) 37 E.L. Rev., 771-784; Jean-Victor Louis, 'The no-bailout clause and rescue packages' (2010) 47 C.M.L.Rev. 971, 977; Jörn Pipkorn, 'Legal arrangements in the Treaty of Maastricht for the effectiveness of the economic and monetary union' (1994) 31 C.M.L.Rev. 275; Harald Hofmeister 'To Bail Out Or Not to Bail Out?-Legal Aspects of the Greek Crisis', (2010-2011) 13 Cambridge Yearbook of European Legal Studies, 113 - 134.

19 T-327/13 Mallis of 21. April 2016 EU:T:2014:909, paras. 41-44, 53.

20 The European Semester was approved by the Member States on 7 September 2010 and the first European Semester cycle was launched in January 2011. See: Regulation (EU) No 1173/2011 of the European Parliament and of the Council of 16 November 2011 on the effective enforcement of budgetary surveillance in the euro area, OJ 2011 L 306/1; Regulation (EU) No 1174/2011 of the European Parliament and of the Council of 16 November 2011 on enforcement measures to correct excessive macroeconomic imbalances in the euro area, OJ 2011 L 306/8; Regulation (EU) No 1175/2011 of the European Parliament and of the Council of 16 November 2011 amending Council Regulation (EC) No 1466/97 on the strengthening of the surveillance of budgetary positions and the surveillance and coordination of economic policies, OJ 2011 L 306/12; Regulation (EU) No 1176/2011 of the European Parliament and of the Council of 16 November 2011 on the prevention and correction of macroeconomic imbalances, OJ $2011 \mathrm{~L}$ 306/25; Council Regulation (EU) No 1177/2011 of 8 November 2011 amending Regulation (EC) No 1467/97 on speeding up and clarifying the implementation of the excessive deficit procedure, OJ 2011 L 306/33; Council Directive 2011/85/EU of 8 November 2011 on requirements for budgetary frameworks of the Member States, OJ 2011 L 306/41

21 European Commission, 'Mastering economic interdependence: Commission proposed reinforced economic governance in the EU', IP/10/561, 12 May 2010 and European Commission, 'EU economic governance: the Commission proposes a reinforced macroeconomic, budgetary and structural surveillance, IP/10/859, 30 June 2010.

22 http://europa.eu/rapid/press-release_MEMO-11-14_en.htm.

23 See for example, the 2015 Communication from the Commission to the EP, the Council, the ECB, the Economic and Social Committee, the Committee of the Regions and the EIB making the best use of the flexibility within the existing rules of the Stability and Growth Pact (COM/2015/012 final).

24 See for instance the 'Alert Mechanism Report 2015', Report from the Commission to the European Parliament, the Council, the European Central Bank and the European Economic and Social Committee, 28 November 2014, COM(2014) 904 final

25 Regulation 1175/2011 amending Regulation 1466/97 on the strengthening of the surveillance of budgetary positions and the surveillance and coordination of economic policies [2011] OJ L306/12; Regulation 1177/2011 amending Regulation 1467/97 on speeding up and clarifying the implementation of the excessive deficit procedure [2011] OJ L306/33; Regulation 1173/2011 on the effective enforcement of budgetary surveillance in the euro area [2011] OJ L306/1; Directive 2011/85/EU on requirements for budgetary frameworks of the Member States [2011] OJ L306/41; Regulation 1176/2011 on the prevention and correction of macroeconomic imbalances [2011] OJ L306/25; Regulation 1174/2011 on enforcement measures to correct macroeconomic imbalances in the euro area [2011] OJ L306/8. 
complementary to the European Semester, in that they provides for strengthened and broadened economic and budgetary surveillance of the Member States (Reg. 1175/2011 and Reg. 1173/2011), for the implementation of the excessive deficit procedure (EDP, Regulation 1177/2011). Furthermore, Regulation 1176/2011 lays out the details of the macroeconomic imbalance surveillance procedure, ${ }^{26}$ while Regulation 1174/2011 applies to all euro zone states and lays out the procedural requirements for sanctions and the 'corrective action plan'. As just noted, the Six-Pack legislation introduces a so called 'excessive deficit procedure' (EDP) which applies to Member States that have breached either the deficit or the debt criterion, imposing through the Council financial sanctions in a gradual way as enforcement mechanisms vis-à-vis non-compliant Member States. ${ }^{27}$ Most sanctions will be determined in the Council under a reverse qualified-majority voting procedure ${ }^{28}$ increasing the likelihood for the euro zone Member States to be sanctioned and strengthening the position of the Commission.

As a result, the Union's economic policy has led to a significant strengthening and widening of EU administrative powers. These are exercised through cooperation and coordination but they can be toughened specifically, when applied in concert with the powers of monetary policy. The result is a considerable de facto transfer of power in the field of economic, fiscal, and social policies to the Union, especially from those Member States within some financial assistance programme or who benefit from ECB measures. This transfer is one from parliamentary law-making and democratically elected governments to a highly complex system of executive cooperation and administrative procedures. As a consequence, although a nascent intergovernmental, European economic executive governance is evolving, it is based largely on administrative action. ${ }^{29}$ Whether such expansion of the 'administrative state' is endowed with adequate tools of accountability will be taken up below.

\section{Organisational and substantive principles in the monetary and economic policy sector}

\section{PRINCIPLES REgARDING THE MONETARY UNION}

When compared with other areas of European administrative law, European monetary union law contains many familiar features, but also ones characterized by certain specificities. Monetary policy for the EU is conducted by the European Central Bank (ECB) in conjunction with the NCBs of those EU Member States belonging to the euro area. ${ }^{30}$ The ECB and the NCBs are the components of the European System of Central Banks (ESCB). The ECB, in some ways structured similarly to an EU agency having its legal basis in the Treaties, ${ }^{31}$ is, again like many agencies, a centre of Union expertise.

However there are some important differences between the ECB and the organization of other Union agencies. The management of monetary policy is an area requiring great technical expertise, and entailing large and substantive risks for the economic wellbeing of all citizens and for the financial positions of Member States. For that reason, it is an eminently political area of law. The relevant Treaty provisions regulate in great detail the internal structure and the independence of the ECB. The ESCB, under Article 130 TFEU, and the ECB according to its statutes a strictly independent. Under Article 130 TFEU 'neither the ECB, nor a national central bank, nor any member of their decision making bodies shall seek or take instructions from Union institutions, bodies, offices or agencies, from any government of a Member State'.

EU law also requires each Member States to ensure the independence of its own NCBs. Article 131 TFEU as well as Article 14(3) Statutes ESCB/ECB (Protocol No 4) require that 'each Member State shall ensure that its national legislation including the statues of its national central bank is compatible with the Treaties and the Statue of the ESCB and of the ECB'. It appears from the legal context of EU monetary policy that independence of the NCBs includes de jure and de facto independence and the possibility for these NCBs to adopt legal acts necessary for implementing ECB policies and guidelines within the ESCB.

26 Regulation 1176/2011 on the prevention and correction of macroeconomic imbalances [2011] OJ L306/25; Regulation 1174/2011 on enforcement measures to correct macroeconomic imbalances in the euro area [2011] OJ L306/8.

27 According to Art 4 of Regulation 1173/2011 countries will now face lodging an interest-bearing deposit of $0.2 \%$ of GDP, upon the Commission's recommendation, if they fail to comply with the recommendations by the Council regarding the preventative arm of the SGP (Medium Term Objective).

28 I.e., a recommendation is deemed to be adopted unless the Council decides by qualified majority to reject it within a given deadline.

29 Christoph Herrmann, Die Bewältigung der Euro-Staatschulden-Krise an den Grenzen des deutschen und europäischen Währungsverfassungsrechts, EuZW (2012) 805-812; Herrmann Joseph Blanke, Stefan Pilz, Solidarische Finanzhilfen als Lackmustest föderaler Balance in der EU, Europarecht (2014), 541-567 at 555.

30 As of 2015 the following 18 Member States who had adopted the euro as their currency: Austria, Belgium, Cyprus, Estonia, Finland, France, Germany, Greece, Luxembourg, Ireland, Italy, Latvia, Lithuania, Netherlands, Portugal, Slovenia, Spain.

31 The ECB evolved out of the European Monetary Cooperation Fund (EMCF) which had been set up by Council Regulation (EEC) No 907/73 of 3 April 1973 (OJ 1973 L 89/2). The EMCF was superseded and its functions assumed by the European Monetary Institute (EMI). This was a temporary body created at the beginning of stage two of the EMU (Art 109f TEC and the EMI statutes attached as a protocol to the TEC). 
Regarding EU monetary policy the ESCB is the central structural innovation established by the Treaties. It is based on a rather unique concept, namely that within the ESCB, the ECB and the NCBs are linked in a very particular way. One factor of this relation touches the role of the NCBs as components of the ESCB. Although the NCBs of those EU Member States - whose currency is the euro - subscribe to the capital of the ECB, ${ }^{32}$ and the shareholders have the right to receive dividend payments, shareholder voting rights are not linked to the share volume held (except as regards decisions on matters such as the distribution of dividends) (Article 10 Statutes $\mathrm{ESCB} / \mathrm{ECB}$ ). Another specific factor in the idiosyncratic linkage concerns the distribution of powers within the ESCB, where much power is concentrated in the ECB, coupled with an important structural element of this administration of monetary policy, namely the decentralisation of duties within the ESCB. ${ }^{33}$ The NCBs are obliged generally to report to the ECB. As well, they are required to implement very detailed policies established by the ECB in Frankfurt. ${ }^{34}$ So, the ECB may give 'the necessary instructions to national central banks' but, as well, may 'have recourse to the national central banks to carry out operations which form part of the tasks of the ESCB ${ }^{35}$ The relation might, then, be regarded as of both a hierarchical and a decentralized nature. ${ }^{36}$ This shows that while, normally, Member State bodies, despite their obligation to comply with EU law and to implement it, do not receive direct administrative instructions from Union bodies, in the field of monetary policy the members of the ECSB are more tightly interlinked, with the NCBs' acting, at least de facto, much as decentralised EU agencies, being obliged to conforms to ECB guidelines.

The ECB's organs are the Governing Council and the Executive Board (Article 129(1) TFEU). The Governing Council comprises the members of the ECB Executive Board together with the governors of each of the NCBs of the euro zone states (Article 283 TFEU). The NCBs are thus not represented as institutions, but rather by individuals as members of an ECB organ. Each member of the Governing Council has one vote, exercised in confidential proceedings. However, voting rights are not allocated on a one-Member-State-one-vote basis as the number of governors with voting rights is limited to 15 .

The Executive Board of the ECB comprises the president the vice president and four other members who are appointed by the Council (Article 283(2) first subparagraph TFEU). Its function is the implementation of monetary policy in accordance with the guidelines and decisions laid down by the Governing Council. Under Article 12 Statues ESCB/ECB

the Governing Council shall adopt the guidelines and take the decisions necessary to ensure the performance of the tasks entrusted to the ESCB under these Treaties and this Statute. The Governing Council shall formulate the monetary policy of the Union including, as appropriate, decisions relating to intermediate monetary objectives, key interest rates and the supply of reserves in the ESCB, and shall establish the necessary guidelines for their implementation.

The Governing Council has committees (themselves supported by working groups comprising NCB staff) which prepare decisions, exchange information, and support uniform implementation of decisions taken. Probably the best known of these was the Banking Supervisory Committee, now transformed into the so called Single Supervisory Mechanism (SSM), ensuring that banking supervision by the ECB occurs in an organisationally separate unit.

Additionally, 'without prejudice to Article 129(1) TFEU, the General Council shall be constituted as a third decision-making body of the ECB', under Article 44 Statues ESCB/ECB (emphasis added). This body is composed of the 'President and Vice-President of the ECB and the Governors of the national central banks. The other members of the Executive Board may participate, without having the right to vote'. Its duties are stated in Article 46 Statutes ESCB/ECB.

When reflecting upon the structure of the ESCB in context of its legal provisions, it appears that it is a highly organised and institutionalised form of interaction, a network of NCBs both within the single structure of, and together with, the ECB. The ECB and NCBs ensure the implementation of the EU monetary policy, the NCBs undertaking much of the supervisory work and the management of minimum reserves, the ECB playing a more policy-setting role. With the introduction of the SSM, the ECB is now also increasingly involved in the

32 Their participation is calculated under Articles 10.1 and 29 Statutes ESCB/ECB taking into account two factors (50\% on the basis of population size of the Member State and $50 \%$ on the basis of its GDP - for the current calculation see https://www.ecb.europa.eu/ecb/orga/capital/html/index.en.html

33 Jochen Hoffmann, Europäisches Währungsverwaltungsrecht, in: Jörg Phillip Terhechte (ed.) Verwaltungsrecht der Europäischen Union, Nomos (Baden-Baden 2011), p. 984 (\$27, para. 8).

34 For the reporting obligations see. Regulation EC 2533/98 of the Council of 23 November 1998, OJ 1998 L 318/8.

35 Art 12(1) of Protocol (No4) on the Statute of the European system of Central Banks and of the European Central Bank establishing that the ECB

36 Jochen Hoffmann, Europäisches Währungsverwaltungsrecht, in: Jörg Phillip Terhechte (ed.) Verwaltungsrecht der Europäisschen Union, Nomos (Baden-Baden: 2011, 984-986 (\$27, paras. 8-11). 
supervision of banking and finance, noting (as above), however, that in doing so a special - rather distinct substructure has been created within the ECB. The structure of the ESCB, largely subject as it is to the authority of the ECB (to which the NCBs stand in a subordinate position, under an obligation to comply with ECB decisions), is a unique construct in the institutional design of the European Union. It is possibly the most centralised approach to agency design so far which established in the Union.

\section{PRINCIPLES REgARDING THE ECONOMIC UNION}

Economic policy of the Union, however, might be regarded - even more than monetary policy - as a field of experimental approaches, not least due to the much less developed set of primary and secondary law provisions. Much of the field of cooperation in economic policy was developed ad hoc in response to the economic crises since 2008. The central legal norm has been Article 126 TFEU, on the prohibition of excessive government deficits and the key means for achieving adherence with this. However, those basic provisions have been expanded by establishing structures, some of which have seemed to be testing notions of constitutionality through the use of existing forms of act in rather creative ways. The pre-ESM 'emergency' response to the 2008 crisis was, for example, heavily premised on private law, notably Memoranda of Understanding (MoU). These often contained strict conditions to be fulfilled by Member States recipient of credit-based funding. This conditionality was spelled out in adjustment programmes to which the recipient countries needed to commit themselves as a prerequisite for loan disbursement. With this, the tool of 'conditionality' entered into the mainstream of EU governance techniques. ${ }^{37}$ Greece, as the first potential defaulter, was also the first Member State to seek assistance within the MoU framework. The Greek MoU provisions were then incorporated into the Council Decision 2010/320/EU ${ }^{38}$ which, based on Art. 126 (9) and 136 TFEU, thereby brought the MoU within the realm of EU law - and thus generating a potential for ensuring its supremacy vis-à-vis national law. ${ }^{39}$ While the idea behind the $\mathrm{MoU}$, and the Council Decision that implemented it, was broadly to reinforce fiscal supervision and reduce the Greek deficit, both the $\mathrm{MoU}$ and the subsequent adjustment programmes ${ }^{40}$ in fact contained a list of very specific, even precise, measures to be undertaken by the country, including measures pertaining to direct taxation, pension maxima, and the abolition of the solidarity allowance.

Another example of the use of forms of private law for achieving macroeconomic goals can be fond in the European Financial Stability Facility (EFSF), established as a private company under Luxembourg law, with Member States as shareholders. This structure, a temporary crisis-resolution mechanism, functioned by issuing bonds and other debt instruments on capital markets, in order to provide financial assistance to Greece, Ireland and Spain. ${ }^{41}$ Finding a linguistically telling characterisation of this construction is not easy. We might borrow the very specific German specific term which emerged for this kind of private law arrangement between states for achieving public goals, Völkerprivatrecht, which might best be translated as 'intergovernmental private law'. ${ }^{42}$

From the perspective of the history of European integration it might not come as a surprise that, in its initial response to these questions, the EU relied to a large extent on the intergovernmental method, despite the familiar difficulties associated with this in terms of decision-making slowness reflecting the need for unanimity. Whether by necessity and/or by design, Union law led to the integration of executive powers through cooperative structures linking governments and executives of Member States and the EU on the basis of public international law, private law, and some European law. The subsequent 'constitutionalisation' of such arrangements, i.e., their integration into the Union's general constitutional framework is an ongoing process. This process includes, though, finding answers to questions of the compatibility of the macroeconomic policy elements addressed here with the principles of democracy and of institutional and administrative transparency, as well as with other underlying constitutional values including fundamental rights.

37 Carol Harlow, Richard Rawlings, Process and Procedure in EU Administration, Hart Publishing (Oxford 2014), 47 referring to this as the 'tough love' approach.

38 See Council Decision 2010/320/EU of 20 December 2010 addressed to Greece with a view to reinforcing and deepening fiscal surveillance and giving notice to Greece to take measures for the deficit reduction judged necessary to remedy the situation of excessive deficit, as amended by Council Decisions 2011/57/EU of 7 March 2011.

39 A series of additional or amending Decisions followed that were founded directly on Art. 121 (4) (Council Decision 2010/190/EU), Art. 126 (8) (Council Decision 2010/29/EU) and Art. 136 TFEU (Council Decision 2010/182/EU).

40 Similarly, the Commission's 'Economic Adjustment Programme for Greece', May 2010 which aims at imposing fiscal stability and a quick reduction in the fiscal deficit, includes immediate increases of VAT and excise taxes, cuts to public sector wages, pensions, social expenditures and public investments.

41 The EFSF no longer provides financial assistance, since this task is now exclusively performed by the ESM. The EFSF however continues to operate to service existing obligations.

42 An alternative, but arguably less telling, translation might be 'public international private law', where the emphasis is crucial for capturing the essence of the idea. 


\section{$D$ Administrative procedures within the fields of monetary and economic policy}

\section{ADMINISTRATIVE PROCEDURES WITHIN THE MONETARY UNION}

In the area of the monetary policy, procedural rules are largely established within the legal framework of the ESCB, and it is the decision-making authorities of the ECB which govern the ESCB (Articles 8 Statutes ESCB/ECB). The ECB's sometimes far reaching decision-making powers emerge from the TFEU, as well as from the Statutes of the ESCB/ECB (in Protocol No. 4). In order to underpin its decision-making authority, Article 132 (1) TFEU confers on the ECB powers to adopt binding acts in the form of both regulations and decisions (under Article 288 TFEU), following special procedures laid down in the Statues. Additionally, Article 132(3) TFEU grants the ECB power to impose pecuniary sanctions on private parties for non-compliance with its acts.

The central task of formulating the monetary policy of the Union is given to the Governing Council of the ECB. Under Article 12(1) Statutes ESCB/ECB, it adopts guidelines and takes the decisions 'necessary to ensure the performance of the tasks entrusted to the ESCB under these Treaties and this Statute', including decisions relating to 'intermediate monetary objectives, key interest rates and the supply of reserves in the ESCB'. The ECB president chairs the Governing Board as well as its Executive Board. The latter is responsible for the ECB's current business, defined in Article 12(2) Statutes ESCB/ECB as the responsibility to 'implement monetary policy in according with the guidelines and decisions laid down by the Governing Council. In doing so the Executive Board shall give the necessary instructions to national central banks'. Generally, the Governing Board decides by a majority vote. Exceptionally, Article 20 Statutes ECSB/ECB, in an open empowerment, allow the Governing Council, by a majority of two thirds of the votes cast, to 'decide upon the use of such other operational methods of monetary control as it sees fit...'

The position of the participant NCBs is clarified in Article 14(3) Statutes ECSB/ECB. According to this, 'national central banks are an integral part of the ESCB and act in accordance with the guidelines and instructions of the ECB. The Governing Council shall take the necessary steps to ensure compliance with the guidelines and instructions of the ECB'.

Monetary policy decisions rely on large quantities of detailed statistical information. In the ESCB, such information is collected predominantly by NCBs from the competent national authorities or economic actors in collaboration with the EU institutions, bodies offices and agencies (Article 5(1), (2) ESCB/ECB Statues). For this purpose, specific rule-making powers on collection and classification of statistical information has been conferred on the ECB (Article 5(3)) and on the Council in the special legislative procedure of Article 129(4) TFEU and Article 41 Statutes ESCB/ECB, to define the natural and legal persons subject to reporting requirements, and cover issues of confidentiality and powers of enforcement.

\section{ADMINISTRATIVE PROCEDURES WITHIN THE ECONOMIC UNION}

As mentioned, the area of economic policy could be regarded even more experimental than the field of monetary policy, seen from the pint of view of EU structure, design, and competence. One reason for this may be that, for monetary policy, frameworks for establishing innovative and highly integrative institutional structures already existed. For economic policy, the initial hope that market forces ensure policy alignment and thus convergent monetary policies went unfulfilled. Instead, institutional structures had to be created ad-hoc, often in situations of acute crisis. In so proceeding, the linking of instruments under public international law with those of Union law has been used to creatively develop the new elements of the EU 'economic constitution'. The 2011 intergovernmental Euro Plus Pact (EPP) ${ }^{43}$ between EU Member States was aimed at strengthening economic policy coordination. ${ }^{44}$ This was later implemented in Union legislation through the above discussed 'Two-Pack' regulations. These were designed to enhance economic integration amongst the euro area Member States, allowing in-depth budgetary-policy monitoring, involving a process which foresees the submission of national budget plans for initial surveillance by the Commission's administration. ${ }^{45} \mathrm{Next}$ to the procedural dimension, the Two-Pack contains substantive criteria, obliging Member States to base their draft budgets on macroeconomic

43 Initially called the Competitiveness Pact or later the Pact for the Euro. See http://www.consilium.europa.eu/uedocs/cms data/docs/pressdata/en/ec/120296.pdf.

44 Conclusions of the EU Summit of 24-25 March 2011, http://register.consilium.europa.eu/pdf/en/11/st00/st00010.en11.pdf.

45 The milestones of this timeline can be summarized, in the framework of the budgetary cycle as follows: By 30 April, euro area Member States must publish their medium-term fiscal plans (Stability Programmes), together with their policy priorities for growth and employment for the forthcoming 12 months (National Reform Programmes) in the context of the European Semester on economic policy coordination; by 15 October, euro area Member States must publish their draft budgets for the following year; by 31 December, euro area Member States must adopt their budgets for the following year. 
forecasting. ${ }^{46}$ As an overall procedural framework for coordinating EU economic policy, Article 121 TFEU establishes so called 'multilateral surveillance', involving the Commission, the European Council, the Council, the European Parliament and the Member States all performing certain functions, taking on certain tasks and having certain responsibilities. ${ }^{47}$

In regard to a certain key areas of economic policy, agreements under public international law have played a major role in the European context. For the granting of financial assistance to Member States of the euro area, the ESM Treaty, a 2012 treaty under public international law, established a mechanism and procedure for the making of loans on the basis of conditionality, in a way similar to that of the earlier forms of assistance. ${ }^{48}$ In the same year, 25 Member States of the EU concluded the public international law Treaty on Stability, Coordination and Governance in the Economic and Monetary Union (TSCG, also known as the Fiscal Compact). The TSCG could arguably have been adopted under EU law as such, either under the enhanced cooperation procedure, ${ }^{49}$ or through an amendment of TEU Protocol No. 12 on the excessive deficit procedure. ${ }^{50}$ However, public international law was chosen in order to overcome the opposition — and veto - of two Member States. ${ }^{51}$ The TSCG was implemented in tandem with above mentioned Six-Pack legislation (and there, is in any case, arguably a considerable overlap between it and the existing EU acquis $)^{52}$ and its full integration into Union law has been proposed. ${ }^{53}$ The Six-Pack measures involved highly complex technical provisions, introducing a managerial type of review of national policy preferences in a host of economic policy areas. The results are computed in seemingly objective approaches based on well-defined calculations, the input into which is however subject to much arbitration. ${ }^{54}$ The ESM and the TSCG were both designed to foster budgetary discipline, to enhance coordination of economic policies, to improve the economic governance of the euro area, and to reinforce the provisions of the initial post-Maastricht Stability and Growth Pact (SGP). ${ }^{55}$

\section{$E \quad$ Legal rules governing the substance of sector-specific decision-making}

\section{DeCISION-MAKING WITHIN THE MONETARY UNION}

According to its legal basis in the Treaties, the ECSB defines and implements the monetary policy of the Union, conducts foreign-exchange operations, manages the official foreign reserves of the Members States, and promotes the 'smooth operation of payment systems' (as noted at the outset of this chapter). In all of this, its prime objective is to maintain 'price stability' (Article 127 TFEU). Additional objectives are adjuvant to the general economic policies in the Union. The competences of the ECB are circumscribed by the prohibition in Article 123(1) TFEU of monetary financing of Member State debt by means of direct purchases (as opposed to open market operations of the ECB, involving Member State bonds).

This broad definition of the tasks, combined with the constitutionally guaranteed independence of the ECB, and the formal obligation of independence of the NCBs as members of the ESCB, results in according a very broad discretion to the ECB in monetary policy decisions. The framing and implementation of monetary policy is undertaken by the ESCB predominantly through the ECB. the To exercise this task it has at its disposal, as Cruz

46 According to Art 4 (4) of Regulation 473/2013 National medium-term fiscal plans and draft budgets referred to in paragraphs 1 and 2 shall be based on independent macroeconomic forecasts, and shall indicate whether the budgetary forecasts have been produced or endorsed by an independent body. Those forecasts shall be made public together with the national medium-term fiscal plans and the draft budgets that they underpin.'

47 Under Art 121(6) the Council and the EP are empowered to adopt detailed rules governing the procedures to apply in this multilateral surveillance, the legal basis for inter alia the Six-Pack measures.

48 According to Bruno De Witte, the addition of par. 3 in Art 136 TFEU would serve first of all, to discard any doubts as to the legality of the establishment of a financial support mechanism for countries in budgetary difficulties and secondly, to neutralise the no bail out prohibition of Art 125 TFEU, by a complementary norm with the same Treaty rank. See Bruno De Witte, 'International Treaties on the Euro and the EU Legal Order' (2012) paper presented in the framework of the EUDO Dissemination Conference 'The Euro Crisis and the State of European Democracy', Florence 22-23 November 2012

$49 \quad$ Art.20 TEU and arts $326-334$ TFEU.

50 Protocol (No 12) on the Excessive Deficit Procedure annexed to the TEU.

51 The only two Member States that did not sign the TSCG were the United Kingdom and the Czech Republic.

52 See, .e.g, Michael Dougan/Michael Gordon, Written Evidence, UK House of Commons, Select Committee on Foreign Affairs 22 May 2012, par. 7-8 (accessible at: https://publications.parliament.uk/pa/cm201314/cmselect/cmfaff/87/87we18.htm).

53 Jean-Claude Junkcer, State of the Union Address 2017, European Parliament, Brussels, 13 September 2017 (accessible at: http://europa.eu/rapid/press-release_SPEECH-17-3165_en.htm).

54 See for detail especially Annex 5 and 6 of the European Commission, Vademecum on the Stability and Growth Pact, May 2013, European Economy Occasional Papers 151, ISSN 1725-3209, pages 90-99.

(http://ec.europa.eu/economy_finance/publications/occasional_paper/2013/pdf/ocp151_en.pdf)

55 Treaty on Stability, Coordination and Governance in the Economic and Monetary Union (Fiscal Compact Treaty), Art 1. 
Villanón AG observed in Gamweiler, technical expertise and access to crucial information enabling it to devise monetary policies which actually influence economic realities. ${ }^{56}$

Such highly technical, very complex, and information-intensive activity is, consequently, very difficult to monitor through the 'traditional' legal means of a framework of power coupled with judicial review. Another, albeit more practical, reason for the difficulty of employing judicial review as a means of enforcing accountability is that most of the decisions of the ECB are directed to the NCBs by way of guidelines. For example, interest rate decisions are directed to the NCBs, without any per se external effect. In principle, this approach makes it exceedingly difficult to ensure judicial review of ECB decisions through direct legal action. More likely of success is an approach involving indirect review, by means of preliminary references to the Court, resulting legal actions relating from national measures and procedures before national courts which grant more liberal standing than a direct approach to the CJEU would encompass. ${ }^{57}$

Criteria of accountability can be decisive in cases involving broad discretion. The fewer the possibilities of judicial review as to the substance of an administrative decision, the more important are procedural considerations as to, for example, satisfaction of a duty of care (specifically, the full and independent assessment of all relevant facts prior to decision-making), compliance with the requirement of having and providing reasons for a measure and, finally, compliance with the principle of proportionality ${ }^{58} \mathrm{With}$ respect to developments in the EMU, it is important to note that 'the principle that powers be exercised proportionally' should not, in the words of Somek, be 'replaced with the principle that powers be proportionate to unpredictable challenges' in times of economic crises or otherwise. ${ }^{59}$

The system for the implementation of EU monetary policy is a highly integrated administrative system in which a special (constitutional) agency - the ECB - is institutionally linked in with the NCBs within the structural and procedural framework of the ESCB. The NCBs themselves must comply with the independence requirements established by primary EU law. They are part of a hierarchical agency structure in which ECB guidelines and decisions are binding. NCBs are, therefore, more like decentralized implementation bodies for centralised decision-making than the more networked structures found in many other areas, where decision-making authority can be seen as more dispersed, distributed and, particularly, shared. That said, the NCBs are bodies established under national law, financed by the Member States, and of which the employees of are subject to Member State law.

\section{DECISION MAKING WITHIN THE ECONOMIC UNION}

On the other hand, as far as economic policy is concerned, much less clear-cut institutional approaches have been laid down by primary law, or by the case law of the courts. Article 119(3) TFEU contains a set of guiding principles for Member State economic policy based on the internal market and an 'open market economy with free competition'. This is applicable 'concurrently', i.e., in parallel, with the implementation of Union monetary policy. Therefore, the just cited provision obliges the Member States to maintain sound public finances and a sustainable balance of payment, the reference to the single market being directed at ensuring free movement of capital (Article 63 TFEU). One of the structural duties of EU monetary policy is the combination of macroprudential activities (such as those listed in Article 18 and 19 Statutes ESCB/ECB) and the banking supervision, now undertaken by the Single Supervisory Mechanism (SSM) located at the ECB and the national central banks.

Further principles are evolving - and are regularly challenged. One example is the so called 'no bail-out clause' (Article 125 TFEU) which was introduced (pre-crisis) in the Treaty of Maastricht, in absence of a fiscal union, apparently in order to avoid (economic) moral hazard within the EU. ${ }^{60}$ This clause, and the subsequent possibility of default for undisciplined participant countries, was the expression of a 'market-based model' assumed to ensure fiscal discipline by states through the pressure emanating from financial markets. This was supposed to imply a 'competitive' and 'decentralized' model for the European macroeconomic constitution. ${ }^{61}$ Such a market-based system is premised on the fact that states should, in principle, have direct access to financial markets in order to fund their expenditures. Lack of fiscal discipline and unsound public finances would be

56 See: Opinion of AG Cruz Villalón in C-62/14 Peter Gauweiler and Others v Deutscher Bundestag of 14 January 2015.

57 An example is the already mentioned case C-62/14 Peter Gauweiler and Others v Deutscher Bundestag of 16 June 2015.

58 See especially C-62/14 Peter Gauweiler and Others v Deutscher Bundestag of 16 June 2015, paras. 66-92.

59 Alexander Somek, Authoritarian Liberalism, 21 European Law Journal 2015, 340-360, at p. 359.

60 The 'moral hazard' in this case would consist in the reduced budgetary discipline of the Member States if the possibility of endless financing by the EU or the ECB was institutionalized. Note however, a strand of economic theory, which argues that 'compulsory' fiscal discipline is not necessary in a Monetary Union as it would not leave any instruments in the Member States' hands to respond to shocks, Buiter, Corsetti and Roubini, 'Excessive Deficits': Sense and Nonsense in the Treaty of Maastricht', (1993) Economic Policy, Reprinted in P. de Grauwe The Political Economy of Monetary Union, (Edward Elgar Publishing Ltd, Cheltenham, 2001), 297331.

61 Miguel Poiares Maduro, We the Court, (Hart Publishing 1998), p. 103 et seq. 
punished, so the market-based model goes, directly through the markets which would stop the lending to the refractory state. The original EMU approach, as enshrined in the Maastricht Treaty, combined elements of both 'competing' approaches. ${ }^{62}$ On the 'market-based side', Article 103 TEC (now 125 TFEU) ${ }^{63}$ established the 'no bail-out clause' in combination with a strict prohibition on 'monetising' debt through the ECB (Article 101 TEC, now 123 TFEU) ${ }^{64}$ while, in respect of the 'central rules system', the Excessive Deficit Procedure (EDP) ${ }^{65}$ and the Stability and Growth Pact (SGP) were directed to guaranteeing fiscal discipline.

\section{$F \quad$ Sector-specific forms of acts and measures}

\section{FORMS OF ACTS AND MEASURES WITHIN THE MONETARY UNION}

The forms of act which have been developed for EU monetary policy are adapted to the particularities of the ESCB. Along with binding regulations and decisions (Article 288 TFEU and Article 34(1) Statutes ESCB/ECB) a specific instrument available to the ECB is that of guidelines (Article 12(1), 14(3) Statutes ESCB/ECB) which are binding upon the NCBs. Additionally, contractual forms of act play an important role.

In practice, regulations are used to outline basic tasks and provide for possible limit on individual rights. ${ }^{66}$ Regulations can be used to establish methods of calculation and determine minimum reserves (Article 19(1) Statutes ESCB/ECB) or to ensure the proper design of payment clearing systems (Article 22 Statutes $\mathrm{ESCB} / \mathrm{ECB}$ ). Decisions can be adopted as 'externally' binding acts, addressing both public and private actors not within the ESCB. Practically, this is predominantly the case in the field of supervision or in requiring minimum reserves. ECB decisions may also be addressed to actors within the ESCB, specifically orders or directions by the ECB to the NCBs, but may also be adopted in the context of self-organisation. ${ }^{67}$

A specifically designed tool of the ECB is the guideline, setting out the general rules within the ESCB and binding the NCBs in their implementation actions. Most of such regulatory activity has occurred through abstract-general guidelines. ${ }^{68}$ Under Article 14(3) Statutes ESCB/ECB, NCBs 'are an integral part of the ESCB and shall act in accordance with the guidelines and instructions of the ECB. The Governing Council [of the ECB] shall take the necessary steps to ensure compliance with the guidelines and instructions of the $\mathrm{ECB}$, and shall require that any necessary information be given to it [by the NCBs]'. One of the difficulties regarding the accountability of the ESCB system (already averred to above) lies in the very instrument of the ECB guideline, binding directly as it does only on the NCBs as participants of the ESCB itself. ${ }^{69}$

Especially in the context of any open market activity, the ECB can act on a contractually, with creditors, debtors, or any other entity. Article 35(2) Statutes ESCB/ECB explicitly acknowledges such activity by stating that disputes arising from such activities 'shall be decided by the competent national courts, save where jurisdiction has been conferred upon the Court of Justice of the European Union'. However, in practice, the ECB, despite explicit empowerment in Article 18(1), does not itself give effect to monetary transactions with financial institutions. Instead, decentralized implementation of so called 'open market' operations is the norm, in turn

62 By 'original EMU approach' we refer to the broad understanding of the 'no bail-out clause' as was perceived by the biggest part of the literature before the Pringle judgment, Case C-370/12 Pringle of 27 November 2012 ECLI:EU:C:2012:756.

63 Art 125 (1) TFEU reads as: 'The Union shall not be liable for or assume the commitments of central governments, regional, local or other public authorities, other bodies governed by public law, or public undertakings of any Member State, without prejudice to mutual financial guarantees for the joint execution of a specific project. A Member State shall not be liable for or assume the commitments of central governments, regional, local or other public authorities, other bodies governed by public law, or public undertakings of another Member State, without prejudice to mutual financial guarantees for the joint execution of a specific project'.

64 The Outright Monetary Transactions Programme (OMT) launched by the ECB has been also called into question. The German Constitutional Court recently referred a preliminary ruling to the CJEU (BVerfG, 2 BvR 1390/12 vom 17.12.2013,

http://www.bverfg.de/entscheidungen/rs20131217 2bvr139012.html), asking, among other questions whether the governments' bond buying in secondary markets by the ECB infringes Art. 123 TFEU and the prohibition of debt monetizing by the ECB. AG Cruz Villalon delivered his Opinion in Gamweiler (C-62/14) on the legality of the OMT scheme of the European Central Bank (ECB) on 14 January 2015, according to which the ECB's OMT programme is compatible, in principle, with the TFEU.

65 Art 126 TFEU (Ex Art 104 TEC).

66 See for example: Regulation (EC) No 2532/98 and Regulation (EC) No 2157/1999 of the European Central Bank of 23 September 1999 on the powers of the European Central Bank to impose sanctions (ECB/1999/4) OJ 1999 L 264/21 as last amended by Regulation of the ECB of 16 April 2014 amending Regulation (EC) No 2157/1999 on the powers of the ECB to impose sanctions (ECB/2014/18), OJ 2014 L 141/51.

67 See e.g. Decision of the ECB of 12 October 1999 concerning the Rules of Procedure of the Executive Board of the ECB (ECB/1999/7), OJ 1999 L 314/34 and the Decision concerning the establishment of the Administrative Board of Review and its Operating Rules (ECB/2014/16), OJ 2014 L 175/47.

68 Jochen Hoffmann, Europäisches Währungsverwaltungsrecht, in: Jörg Phillip Terhechte (ed.) Verwaltungsrecht der Europäisschen Union, Nomos (Baden-Baden: 2011), 989 ( $\$ 27$, para 19).

69 The implementation of ECB monetary policy takes place within the rules established by ECB/2011/14, Guideline of the ECB of 20 September 2011 on monetary policy instruments and procedures of the Eurosystem, OJ 2011 L 331/1. 
explaining the absence of an explicit legal framework for ECB triggered monetary transactions. Instead, open market operations conducted by the NCBs are conducted under national law and it is, therefore, for that law to determine the forms of act for such operations within its jurisdiction. It is specifically for national administrative law to determine whether an NCB has a choice between forms of act and what the consequences of such a choice might be as regards, for example, judicial review and enforceability. However, the choice of law - public or private law - may lead to varied consequences regarding ECB guidelines, both with respect to enforcement and for the sanctioning of non-compliance.

\section{FORMS OF ACTS AND MEASURES WITHIN THE ECONOMIC UNION}

Given the very different configuration of actors in the field of EU economic policy, an entirely different, but specific, typology of acts has developed. Forms of act with abstract-general content can, in some instances, be adopted as Union acts under Article 288 TFEU (e.g., Two-Pack and Six-Pack legislation). Additionally, forms of what have been called 'intergovernmental private law' and international agreements have been developed. A powerful instrument under the former is the Memorandum of Understanding $(\mathrm{MoU})$, attached to intergovernmental financial support agreements establishing the conditions of loans and the terms of repayment. As such, they have the power indirectly to shape the creation and enforcement of national law. MoUs applicable in a specific loan agreement have in the past, however, later been attached to a Council measure and have thereby changed their nature from inter-partes agreements to that of a generally applicable Union act, endowed with the principles of supremacy and direct effect. That practice is, however, rather problematic, since the transfer of contractual terms into binding Union legal acts changes the enforcement possibilities, and may need to be reviewed regarding the procedural conditions for its creation. On the other hand, economic policy of the Union is per se not a field of single-case decision-making, but realised rather through broad, macroeconomic policy choices and associated measures.

\section{$G$ Administrative enforcement in monetary and economic policy}

\section{ENFORCEMENT WITHIN THE MONETARY UNION}

With regard to individuals, the ECB has the power to sanction non-compliance with monetary policy established by the ESCB. Under Article 34(3) Statutes ESCB/ECB the Council can empower both the ECB and NCBs to impose financial penalties on banks and other financial institutions directly: 'Within the limits and under the conditions adopted by the Council under the procedure laid down in Article 41, the ECB shall be entitled to impose fines or periodic penalty payments on undertakings for failure to comply with obligations under its regulations and decisions.' Further details on the powers of the ECB to impose sanctions are established in ECB Regulations 2532/98 and 2157/1999. ${ }^{70}$

With respect to Member States, the ECB has considerable de facto powers to influence even economic policies, as a result of its powers in the context of monetary policy. The main tool for this is, alongside the formal conditionality of financial instruments, also the informal conditionality of ECB actions upon Member States' action in carrying out specific measures of economic reform. Beukers reports that this has been part of the ECB's unconventional monetary policy. Examples are sovereign bond buying under the Securities Markets Programme, ${ }^{71}$ the Outright Monetary Transactions, ${ }^{72}$ and measures related to the solvency of financial institutions in granting - or withholding - Emergency Liquidity Assistance in cases where the solvency of financial institutions is not secured through EU/IMF programmes. ${ }^{73}$ The ECB is in practice involved in formulating the conditionality of the EU/IMF programmes, not least by supplying expertise and information, but sometimes through more direct intervention, e.g., as part of the 'Troika' (now known - perhaps less pejoratively - as the 'institutions'). In these instances, the ECB acts in assisting the formulation of economic policy measures for a Member State, non-compliance with can be sanctioned by the Bank with serious threats to the liquidity of the banking system (and with it the functioning of the entire economy) of the Member State concerned. The expertise-driven independent EU agency that is the ECB thus has at its disposal extremely

70 Regulation (EC) No 2532/98 and Regulation (EC) No 2157/1999 of the European Central Bank of 23 September 1999 on the powers of the European Central Bank to impose sanctions (ECB/1999/4) OJ 1999 L 264/21 as last amended by Regulation of the ECB of 16 April 2014 amending Regulation (EC) No 2157/1999 on the powers of the ECB to impose sanctions (ECB/2014/18), OJ 2014 L 141/51.

71 ECB Press Release of 21 February 2013 on the Eurosystem's holdings of securities acquired under the Securities Markets Programme (SMP).

72 ECB Press Release of 11 March 2016 on OMTs and their conditions which led to Case C-62/14 Peter Gauweiler and Others v Deutscher Bundestag of 16 June 2015.

73 ECB Press Release of 21 March 2012 stating that as of 25 March 2013, 'Emergency Liquidity Assistance (ELA) could only be considered if an EU/IMF programme is in place' that would ensure the solvency of the concerned banks as was the case of Cyprus, Ireland and Greece. 
powerful tools for demanding compliance with centrally — or at least collectively — determined economic policy approaches.

Beukers cites three cases in which the ECB also tried to link its support for Member States' financial institutions through secretly issuing warnings regarding compliance with economic policy goals. Letters of this kind have demonstrably been sent by the president of the ECB to Italy, Spain, and Ireland at various times during the crises. The letter to Ireland warns, for example, that 'future decisions of the Governing Council of the ECB regarding the terms of liquidity provision to Irish banks will thus need to take into account appropriate progress in the areas of fiscal consolidation' by the Republic of Ireland. ${ }^{74}$

\section{ENFORCEMENT WITHIN THE ECONOMIC UNION}

In economic policy, the options for enforcement are spelled out essentially in Article 126(11) TFEU and Regulations $1173 / 200^{75}$ and $1174 / 2011^{76}$ (part of the Six-Pack legislation), requiring budgetary surveillance and the prohibition of excessive debt and economic imbalances. The budgetary surveillance mechanism (Regulation 1173/2011) lists various infractions, such as not taking action to tackle excessive deficits or misrepresentation of deficits, and establishes enforcement mechanisms. Sanctions include ordering Member States to make interest bearing deposits (Article 4) or non-interest bearing deposits (Article 5) or to pay fines 'amounting to $0.2 \%$ of the Member State's GDP' imposed by the Council acting under Article 126(8) TFEU (Article 6). Enforcement powers regarding the policing of the prohibition of excessive debt and economic imbalances are thereby conferred on the Council. Also, under Article 3(1) Regulation 1174/2011, Council decisions establishing noncompliance in accordance with Article 10(4) Regulation 1176/2011 may lead to interest-bearing and non-interest bearing deposits, as well as, under Article 3(2), to fines. In these cases, the Council acts on a Commission recommendation. In certain cases, the Council may further transpose the interest-bearing deposit into an annual fine. However, in view of the difficulties in finding majorities in the Council for such actions - especially since Member States are called upon to sanction each other, and to impose fines on countries already in financial difficulty - the decision-making procedure for the imposing fines is simplified in that the 'decisions referred to in paragraphs 1 and 2 [of Article 3 Regulation 1174/2011] shall be deemed adopted by the Council unless it decides, by qualified majority, to reject the recommendation within 10 days of its adoption by the Commission'. However, the Council has also some leeway with regard to the decision as there is no need for unanimity because, under the Regulation, 'the Council may decide, by qualified majority, to amend the [Commission's] recommendation'. This is not atypical for Council administrative action, in contrast with its procedures when acting in a legislative capacity. The Regulations provide the Member States with certain rights of defence. These may be further developed in case law should challenges come before the Court, but this has so far not occurred given the rarity of the Council's use of these enforcement measures. Nonetheless, this is an impressive example of the reach of administrative powers (and the significance of the associated legal framework, procedures and structures) in European Union law. A 'recommendation' by the Commission, followed by a Council decision, can be enforced by the imposition of deposit requirements and fines, large enough so as to be able to influence a Member State's economic development and force it to take certain economic policy decisions.

Additionally, Regulation 1303/2013 allows for suspension of payments under the European Structural Funds (ESF) mechanism in cases of established violations of the conditionality of funding (such as complying with rules on budgetary surveillance, on excessive debt as well as on economic imbalances. ${ }^{77}$

\section{$H$ Supervision and control of European economic and monetary policy}

\section{SUPERVISION WITHIN THE MONETARY UNION}

In the realm of monetary policy, the strict independence of the ECB does not exclude its being subject to certain forms of supervision. Nevertheless, there is very little anticipatory control, other than through the policy and structural frameworks deriving from the specific legislative acts applying to the ESCB. One such ex ante (political) control emerges from the nomination process for the chief personnel of the ECB. For example, the President of the ECB, who chairs the Executive Board, the Governing Council and the General Council, is

74 Letter of Jean Claude Trichet, President of the ECB to Brian Lenihan, Minister for Finance of Ireland, of 15 October 2010.

75 Regulation (EU) No 1173/2011 of the European Parliament and of the Council of 16 November 2011 on the effective enforcement of budgetary surveillance in the euro area, OJ 2011 L 306/1.

76 Regulation (EU) No 1174/2011 of the European Parliament and of the Council of 16 November 2011 on enforcement measures to correct excessive macroeconomic imbalances in the euro area, OJ $2011 \mathrm{~L}$ 306/8.

77 Regulation (EU) No 1303/2013 of the European Parliament and of the Council of 17 December 2013 laying down common provisions on the European Regional Development Fund, the European Social Fund, the Cohesion Fund, the European Agricultural Fund for Rural Development and the European Maritime and Fisheries Fund and laying down general provisions on the European Regional Development Fund, the European Social Fund, the Cohesion Fund and the European Maritime and Fisheries Fund and repealing Council Regulation (EC) No 1083/2006, OJ 2013 L 347/320. See e.g. Art. 23 'Measures linking effectiveness of ESI Funds to sound economic governance'. 
appointed (by majority vote) in the European Council for an eight-year non-renewable term. However, this longterm appointment and the non-renewability, while underlining the legislative objective of genuine independence, clearly weakens such control in comparison with other policy fields.

On-going supervision - broadly ex post, because in the form of reporting - relies very much on the accuracy of the ECB's own reporting. In that regard, an important supervisory instrument under Article 15(2) ESCB/ECB Statues (Protocol No 4) consists of the 'consolidated financial statement of the ESCB', published weekly and 'available to interested parties free of charge' (Article 15(4)). These statements are important especially with regard to the ECB's financial arrangements, which are separate from those of the EU, the ECB having its own budget and its capital being subscribed and paid up by the euro area NCBs. (Whether such 'supervision' is to be regarded as administrative or political in nature is perhaps a moot point, not needing further clarification here.)

Subsequent, expost, (administrative) supervision also takes place, according to the Statute of the ESCB, through two interacting layers of auditing, one by external private auditors, the other by the EU's own auditing body, the European Court of Auditors (ECA). External auditors assessments of the ECB's annual accounts (Article 27.1 Statute ESCB/ECB) are published as part of the ECB Annual Report. The ECA, on the other hand, examines the operational efficiency of the management of the Bank (Article 27.2). The reason for such distinction, and for a layer of external audit in addition to the scrutiny of the ECA, is not entirely clear.

The ECB Governing Council had initially attempted to prevent anti-fraud review of the Bank by the Commission's anti-fraud office OLAF, ${ }^{78}$ with the argument that that the ECB's independent position and its statutory tasks precluded application of the OLAF Regulation to it. The Court of Justice held this to be in violation of EU law. ${ }^{79}$ According to the Court, the guarantee of independence for the ECB does not have the consequence of separating it entirely from the whole framework of the Union and exempting it from every rule of EU law. In adapting to this judgment, the Governing Council has accepted OLAF investigations. ${ }^{80}$ Tensions, however, linger, with the ECB's assertion that application of the OLAF Regulation could be a threat the independent performance of its tasks. For this reason, special working arrangements were agreed between OLAF and the ECB in $2016 .^{81}$ As well as being subject OLAF review, the ECB is also subject to scrutiny by the European Ombudsman (and its powers of reporting to the European Parliament). With regard to data information, date processing by the ECB is subject to control by the European Data Protection Supervisor (EDPS). ${ }^{82}$

Judicial review in respect of the administration of EU monetary policy is limited due to the highly technical and discretionary procedures of the ESCB, as well as by the general lack of individuals standing in annulment actions against ECB measures. ${ }^{83}$ Nonetheless, judicial review plays an important role in the overall control of ECB activity. The Ganweiler OMT case is an example of highly publicised disputes in regard to the legality of ECB monetary policy decisions. ${ }^{84}$ Judicial review also takes place with regard personnel matters, access to documents, and transparency issues. ${ }^{85}$ Article 35 Statutes ESCB/ECB enables the Court to review and interpret 'the acts or omissions of the ECB'. Problematic for this, though, are the 'open market operations' in which the ECB may act merely on a contractual basis, where disputes may arise between the ECB and its creditors. These disputes 'shall be decided by the competent national courts [under the national law applicable], save where jurisdiction has been conferred upon the Court of Justice of the European Union' (Article 35(2) Statutes ESCB/ECB). Irrespective of such national court review over the legal position of the $\mathrm{ECB}$, the Bank is subject to the liability regime provided

78 In 1999 the European Parliament and the EU Council adopted Regulation (EC) No. 1073/1999 concerning investigations carried out by the European Anti-Fraud Office ('OLAF Regulation') in order to step up the fight against fraud, corruption and other illegal activities detrimental to the Communities' financial interests. It mainly provides for the internal investigation by OLAF of suspected fraud within EU institutions, bodies, offices and agencies.

79 See Case C-11/00 Commission v ECB [2003] ECR I-7147, ECLI:EU:C:2003:395.

80 ECB Decision on the rules applying to OLAF investigations - The Governing Council of the European Central Bank adopted on 3 June 2004 a Decision (ECB/2004/11) concerning the terms and conditions for European Anti-Fraud Office investigations of the European Central Bank, in relation to the prevention of fraud, corruption and any other illegal activities detrimental to the European Communities' financial interests and amending the Conditions of Employment for Staff of the European Central Bank. This Decision entered into force on 1 July 2004.

81 Administrative Arrangements between the European Central Bank and the European Anti-Fraud Office of 16 June 2016, https://www.ecb.europa.eu/ecb/pdf/orga/Administrative-Arrangements-between-ECB-and-European-Anti-Fraud-Office.pdf (last viewed on 1 March 2017).

82 See Art 46 of Regulation (EC) No 45/2001 of 18 December 2000 on the protection of individuals with regard to the processing of personal data by the Community institutions and bodies and on the free movement of such data, OJ 2001 L 8/1.

83 For difficulties to bring cases against decisions or guidelines of the ECB by individuals see e.g. Case C-64/14P Sven A. von Storch and Others v European Central Bank of 29 April 2015 ECLI:EU:C:2015:300 (on appeal against the order of the General Court of 10 December 2013 in Case T-492/12).

84 Case C-62/14 Peter Gawweiler and Others v Deutscher Bundestag of 16 June 2015.

85 See e.g. Order of the Court in Case C-28/13 P Thesing and Bloomberg Finance v ECB of 6 February 2014, ECLI:EU:C:2014:230. 
for in Article 340 TFEU. Since the NCBs are themselves liable in accordance with their respective national laws, cases of the possible joint liability with the ECB will result in complex legal questions.

Beyond such judicial review possibilities, the ECB itself has standing to bring legal action (Article 35 Statutes ESCB/ECB). Further, it may be able to avail itself of the jurisdiction of the CJEU within an arbitration clause contained in a contract concluded by, or on behalf of the $\mathrm{ECB}$, whether that contract be governed by public or private law (Article 35(5) Statutes ESCB/ECB). Under that provision, the CJEU has jurisdiction in disputes concerning the fulfilment by a national central bank of obligations under the Treaties and this Statute'.

In order to address disputes between the ECB and the $\mathrm{NCBs}$, a simplified action under the infringement procedure is available. Article 35(6) Statutes ESCB/ECB provides that if

the ECB considers that a national central bank has failed to fulfil an obligation under the Treaties and this Statute, it shall deliver a reasoned opinion on the matter after giving the national central bank concerned the opportunity to submit its observations. If the national central bank concerned does not comply with the opinion within the period laid down by the ECB, the latter may bring the matter before the Court of Justice of the European Union.

Article 271(d) TFEU explicitly states that the powers given to the ECB Governing Council in respect of alleged violations of $\mathrm{NCB}$ obligations shall be 'the same as those conferred upon the Commission in respect of Member States by Article 258 TFEU. The ECB can then ensure that the national banks comply with their obligations established by ECB guidelines. So far, however, no case law, equivalent to that where fines under Articles 258260 TFEU have been imposed, especially for repeat violations of EU law, has emerged under these provisions.

\section{SUPERVISION WITHIN THE ECONOMIC UNION}

In the context of the economic union, possibilities of judicial review reflect a particular intergovernmental (public international law) approach. Any Commission finding of inadequate implementation of the balanced budget rule requires the country concerned to be brought before the Court of Justice by another state. ${ }^{86}$ Article 8(1) TSCG provides for recourse to the CJEU via Art. 273 TFEU (which accords jurisdiction to the Court in any dispute between Member States which relates to the subject matter of the EU Treaties) if the dispute is submitted to it under a special agreement between the parties. ${ }^{87}$ However, experience shows that Member States will only very rarely take each other to court. If the Commission is not empowered to start infringement proceedings against a Member State - and judging by the letter of the Fiscal Compact (FCT), as well as the TEU and TFEU, it is not able to do so -, and one country within the TSCG does not bring another member before the Court, it seems likely that a violation of Article 3 TSCG (on the FCT) will not trigger a sanction for the noncompliant state. Many elements of this approach have been criticised in the literature. Perhaps most centrally, the nature of this economic framework as an international treaty means that it does not prevail over national constitutions, thus arguably weakening its supervision and enforcement mechanisms. ${ }^{88}$ The indirect possibility of the conferral of new powers to the EU institutions, notably the Commission, by the TSCG has further raised concerns about legality. ${ }^{89}$ Arguably, however, the agreement should be seen as carefully drafted in such a way so as not to give EU institutions new competences - which might have triggered the necessity for referenda in certain states prior to ratification -, but rather new tasks falling within their existing competences, which the Commission and the Council are under no obligation to perform.

\section{Conclusion}

Although monetary and economic policies are highly interrelated, as in most national systems, there are in the Union context also great differences in the legal and administrative framework governing the two fields. The

86 Treaty on Stability, Coordination and Governance in the Economic and Monetary Union (Fiscal Compact Treaty), Art 8(1): 'Where a Contracting Party considers, independently of the Commission's report, that another Contracting Party has failed to comply with Art 3(2), it may also bring the matter to the Court of Justice. In both cases, the judgment of the Court of Justice shall be binding on the parties to the proceedings, which shall take the necessary measures to comply with the judgment within a period to be decided by the Court of Justice. According to Art 8 (2), failure to comply with a judgment may result in further proceedings in which the Court of Justice may impose a lump-sum or penalty payment of $0.1 \%$ GDP. For euro zone Members this money will be paid into the European Stability Mechanism while for non-euro zone states it will be paid into the general EU budget.

87 See Council of the European Union 5788/12 (Brussels, January 26, 2012) and P. Craig, 'The Stability Coordination and Governance Treaty: principle, politics and pragmatism' (2012) 37 E. L. Rev, p. 245.

88 For the distinction see B. De Witte, 'Another Legal Monster? An EUI Debate on the Fiscal Compact Treaty', EUI Working Paper Law 2012/09, p. 5-7.

89 According to Art 13(2) TEU, the EU institutions shall act within the limits of the powers given to them under 'the Treaties' (i.e. the TEU and the TFEU). For the doubts as to the legality of the attribution of new powers, see House of Lords - European Union Committee, 'The Euro Area Crisis: 25th report of session 2010-2012, (14 February 2012). However, also see Michael

Dougan/Michael Gordon, Written Evidence, UK House of Commons, Select Committee on Foreign Affairs 22 May 2012, par. 1113 (accessible at: https://publications.parliament.uk/pa/cm201314/cmselect/cmfaff/87/87we18.htm). 
implementation of European monetary policy is set within a system of independent but tightly linked 'agencies' consisting of the European Central Bank (ECB) and the national central banks (NCBs), within the European System of Central Banks (ESCB). These bodies have powers guaranteed in the primary law of the European Union. Much of the specification of the instruments and procedures for ECB decision-making is concentrated in the Treaties, together with the Statues of the ESCB/ECB (in Protocol No. 4 to the TEU and TFEU).

Monetary policy conducted within the ESCB's specific structure of decentralised Union administration is a case study of a highly integrated agency regime in which a Union authority - the ECB - takes the decisions, and the national agencies implement the (binding) 'guidelines' issued by it. No other EU policy area has reached this level of quasi-federal agency-structure. At the same time, EU monetary policy has become an revealing field for the study of agency independence, and of the powerful role which specialist expertise can play in articulating a highly important and precisely focussed objective: that of guaranteeing price stability. This closely defined policy goal is one to be exercised, where possible, so that the maintenance of price stability contributes to the 'general economic policies in the Union'. It is thus a technical objective, but one to be exercised in the context of politically defined goals. Therefore, one must conclude that the 'administration' of the Union's monetary policy is a highly political one.

The legal framework of the other major branch of the sector addressed in this chapter, European Union economic policy, has been, and is, in the process of continuous transformation or evolution. The economic and financial crises from 2008 onwards have been catalytic for accelerating integration. Some of the measures adopted have, however, gone deeper than simply strengthening the previous policy framework. Some have changed the details of the EMU roadmap both from an institutional and constitutional perspective.

Under this umbrella the EU was, in the bid to find new 'governance techniques', compelled to supplement its economic policy toolbox with novel instruments of governance and administration. It has resorted to public international law instruments (such as the Fiscal Compact) and intergovernmental private law instruments (ESM, MoUs). Arguably, it was possible by these means to circumvent EU procedural rules which permitted for national vetoes and - in part - even Union constitutional principles. For example, the adjustment programmes premised on the MoUs laid out very specific lists of measures to be fulfilled by the recipient Member States, including measures pertaining to direct taxation and social policy. ${ }^{90}$ Limits on further integration in this field result both from the Treaties (e.g., the prohibition of monetary financing of national budgets) and from national constitutional law limiting steps towards further financial integration. That said, it should be noted - and can be persuasively argued - that the 'TSCG is an international agreement entirely separate from and constituting no [at least formal] part of the EU legal order...[and] must be interpreted and applied in conformity with EU law, the latter taking precedence in the event of any conflict between the two regimes'. ${ }^{91}$

Whilst these ad-boc 'crisis measures' are, on the one hand, highly technical, requiring sophisticated mastery of detail by expert regulators, they are also deeply political. The conditionalities attached to any (pre- or post-ESM) financial assistance, as well as the Country Specific Recommendations made by the Commission to the Member States, have direct and immediate implications for the economic and social policy choices for the future of Europe and its Member States, pertaining, for instance, to employment, social security and taxation. By being brought within the realm of the Union, they are, however, transformed. No longer exclusively subject to national legislative and political choices, they are, instead, brought within the realm of the supranational governance of the European Union, and thereby that of its public administration and administrative law. This is not, per se, objectionable, but needs to be acknowledged squarely. The reasoning behind such a shift from purely national policy-making and implementation to the setting of supranational policy and European administrative law lies in the objective of a strengthened and more efficient achievement of the objectives of Union economic policy and law, based in particular on the perceived need for stronger technocratic oversight of national economic management. ${ }^{92}$ Economic policy cooperation has, therefore, led to profoundly technocratic attempts at ensuring compliance with certain framework parameters, in particular those of indebtedness and growth. The means of achieving these objectives are now prescribed by the Commission as an executive body, issuing policy suggestions regarding tax reform, as well as transport, environmental, educational, health and much other policy, suggestions which can be made quasi-binding for, in particular, so called 'programme countries'.

\footnotetext{
$90 \quad$ See section 3.2.1.

91 Michael Dougan/Michael Gordon, Written Evidence, UK House of Commons, Select Committee on Foreign Affairs 22 May 2012 , par. 7 (accessible at: https://publications.parliament.uk/pa/cm201314/cmselect/cmfaff/87/87we18.htm)

92 Huw Macartney, 'The paradox of integration? European democracy and the debt crisis' (2014) Cambridge Review of International Affairs,
} 12. 
For the legitimate exercise of this economic policy role, the Commission and indeed the Union as a whole seen at least from the classic perspective of the democratic state under the rule of law - arguably need a very different democratic mandate from the one that exists today. European economic governance as it has been evolving, requires a 'higher' level of democratic legitimacy than provided for the various recent intergovernmental policies and their formal EU equivalents. Strongly intergovernmental or purely administrativetechnocratic approaches cannot claim this legitimacy, since they cannot ensure that the views and interests of those affected by such decisions and measures have influenced, or can potentially influence, the policy choices made. Here inevitably follow two profound, interlinked future research questions: Does the European Union in its existing political-institutional conception and architecture have the capacity of providing such a framework of legitimacy. Secondly, (if so), what means and specific steps are needed in order to usher in the steps necessary for realising and extending this potential, and within what timeframe?

Overall, one can observe that the policy field of the economic and monetary union has many specificities. The highly integrated monetary union relying on an administrative-intergovernmental economic policy review creates a very particular and interrelated set of policies and implementation tools. However, despite the many individual - perhaps unique - features, this area actually also offers itself as one with a wealth of examples for many of the general characteristics - and the problems - of the fast-evolving administrative law of Union seen as a whole..$^{93}$ In this respect, we see that the policy objectives of the economic and monetary union are clearly defined in Treaty provisions, and that therefore the functional objectives of this policy clearly have a (pan-)European focus and orientation. Nonetheless, the (administrative) actors involved are themselves located either on the European level (ECB, Commission, Council, European Council, European Parliament) or on the national level under national law (NCBs, national governments and parliaments). No actors can be described as truly joint EU and Member State bodies, i.e., from an organisational point of view, there is no strictly joint and/or fused national and European organizational entity. However, the two levels are indeed integrated, through intricate procedural - and to some extent structural - cooperation.

In monetary policy this cooperation occurs through the ESCB in which, quite atypically, a hierarchic command relation exists between the ECB and the NCBs. The atypical nature here can be noted more explicitly: the ESCB is, in effect, a classic example of an EU network, but such networks typically have no hierarchical decision-making element. More particularly, such networked structures - which run throughout EU administrative law - are mostly so constructed that, where a central Union body is involved (typically the Commission), it has only a steering function, but no vote in final decision-making (e.g., as it is in comitology committees). Here in the field of monetary policy, though, the ECB is considerably more than a primus inter pares in the ESCB; rather it has a virtually dominant role.

In the area of economic policy, intergovernmental cooperation is supplemented by the administrative review of national policies of the Member States, and by what I have referred to above as intergovernmental private law. The unusual nature of this as a European administrative phenomenon and its complicating implications for EU administrative law arise here from the elaborate procedures which link the various actors together in diverse arrangements which make use of creatively devised forms of act. Problems arise in a context of such variable character, then, in regard to the allocation of responsibilities, issues of transparency, and accountability mechanisms. The stronger the moves toward more multi-level but integrated, administrative procedures of these kinds, the more pronounced and urgent becomes the need for clear democratic legitimation of European executive action.

93 Herwig C.H. Hofmann, Gerard C. Rowe, Alexander H. Türk, Administrative Law and Policy of the European Union, Oxford University Press (Oxford 2011), 18. 